Int. J. Electrochem. Sci., 12 (2017) 10553 - 10566

International Journal of

ELECTROCHEMICAL

SCIENCE

www.electrochemsci.org

\title{
Simultaneous Sulfide Removal and Hydrogen Production in a Microbial Electrolysis Cell
}

\author{
Zhi-shuai Dong ${ }^{1}$, Yu Zhao ${ }^{1 *}$, Lei Fan ${ }^{1}$, Yu-xue Wang ${ }^{1}$, Jun-wen Wang ${ }^{1 *}$, Kan $_{\text {Zhang }}{ }^{2}$ \\ ${ }^{1}$ College of Chemistry and Chemical Engineering, Taiyuan University of Technology, Taiyuan, Shanxi, \\ P. R. China, 030024 \\ ${ }^{2}$ Institute of Coal Chemistry, Chinese Academy of Sciences, Taiyuan 030001, PR China \\ *E-mail: zhaoyu@tyut.edu.cn, wangjunwen@tyut.edu.cn
}

doi: $10.20964 / 2017.11 .53$

Received: 24 July 2017 / Accepted: 6 September 2017 / Published: 12 October 2017

Sulfide removal and hydrogen production in a microbial electrolysis cell (MEC) were simultaneously accomplished using potassium sulfide as the substrate. Experiments were conducted utilizing a singlechamber MEC under the applied voltage of $0.7 \mathrm{~V}$ with different concentrations of potassium sulfide (i.e., 500, 600, 800, and $1000 \mathrm{mg} / \mathrm{L}$ ). MEC test results indicated that the optimum concentration of potassium sulfide was $600 \mathrm{mg} / \mathrm{L}$ with a maximum hydrogen production rate $\left(Q_{H 2}\right)$ and overall energy recovery $\left(\eta_{w+s}\right)$ of $0.913 \pm 0.023 \mathrm{~m}^{3} \mathrm{H}_{2} \mathrm{~m}^{-3} \mathrm{~d}^{-1}$ and $261 \% \pm 6.5 \%$, respectively. The sulfide removal rate was $80.7 \%$. Microbial community analysis of the anode biofilm showed an extensive diversity of bacteria, including Geobacter(7.35\%), Desulfurella(4.31\%), Sulfuricurvum(3.33\%), and Sulfurospirillum(2.82\%). This study presents a new and effective method for sulfide removal.

Keywords: Sulfide removal; Hydrogen generation; Microbial community diversity; Microbial electrolysis cell

\section{FULL TEXT}

(C) 2017 The Authors. Published by ESG (www.electrochemsci.org). This article is an open access article distributed under the terms and conditions of the Creative Commons Attribution license (http://creativecommons.org/licenses/by/4.0/). 